\title{
WHAT MAKES PRODUCT DEVELOPMENT MARKET ORIENTED? TOWARDS A CONCEPTUAL FRAMEWORK
}

\author{
ROBERT A. W. KOK* and BAS HILLEBRAND ${ }^{\dagger}$ \\ Nijmegen School of Management \\ P.O. Box 9108, 6500 HK Nijmegen, The Netherlands \\ *r.kok@nsm.kun.nl \\ ${ }^{\dagger}$ b.hillebrand@nsm.kun.nl \\ WIM G. BIEMANS \\ Faculty of Management \& Organization, University of Groningen \\ P.O. Box 800, 9700 AV Groningen, The Netherlands \\ w.g.biemans@bdk.rug.nl
}

Received 22 August 2002

Revised 31 March 2003

Accepted 3 April 2003

\begin{abstract}
While there is quite some literature on the relationship between market orientation and product development, it is still unclear what market-oriented product development really is. In this article the authors present a conceptual framework detailing the elements of market-oriented product development and the relationships between these elements. More specifically, market-oriented product development is conceptualised as a combination of specific capabilities and market information processing activities. These capabilities encapsulate the values and norms, knowledge and skills, technical and managerial knowledge systems, which enable learning about markets through information processing behaviour in product development and improve this market learning behaviour. As such it is argued that market-oriented product development may be regarded as an organisational learning capability.
\end{abstract}

Keywords: Market orientation; product development; organisational learning; capability.

\section{Introduction}

Since the 1990s, market orientation pervades academic research and management practice. It is rooted in marketing theory as the operationalisation of the marketing concept and concerns learning about the market by developing an understanding of the market and using it for marketing actions. The relationship between market 
orientation and business performance indicators has been studied extensively and most studies report a positive, if moderated, relationship for various markets (e.g. Avlonitis \& Gounaris, 1997; Baker \& Sinkula, 1999a; Baker \& Sinkula, 1999b; Gatignon \& Xuereb, 1997; Greenley, 1995; Han, Kim \& Srivastava, 1998; Hurley \& Hult, 1998; Jaworski \& Kohli, 1993; Narver \& Slater, 1990; Pelham \& Wilson, 1996; Ruekert 1992; Slater \& Narver, 1994; Slater \& Narver, 1996; Slater \& Narver, 2000).

The product development literature also emphasises the importance of having a market orientation (e.g. Atuahene-Gima, 1995; Barclay, 1992; Cooper, 1983; Cooper \& Kleinschmidt, 1993; Cooper \& Kleinschmidt, 1994; Cooper \& Kleinschmidt, 1995; Li \& Calantone, 1998; Montoya-Weiss \& Calantone, 1994; Wren, Souder \& Berkowitz, 2000). In their meta-analysis, Montoya-Weiss and Calantone (1994) conclude that a large number of studies state that, among others, factors related to market orientation determine new product performance. That is, these factors are either a part of a market orientation (such as proficiency of predevelopment activities, proficiency of marketing activities, and protocol) or a consequence of having a market orientation (such as product advantage).

But even though there is quite some literature on the relationship between market orientation and product development and the literature indicates the significance of market oriented product development, it is all but silent on what market oriented product development is. Hardly any study reports on the conceptualisation and operationalisation of market orientation in the managerial context of a specific critical process like product development (Barclay, 1992; Day, 1994b; Poolton \& Barclay, 1998). Such studies are relevant for two reasons. First, when managers do not know how to operationalise market oriented product development, they are unable to identify what needs to be changed to make their product development activities more market oriented. As Han et al., (1998, p. 31) state: "a market orientation remains incomplete if practitioners do not understand the modus operandi that gives rise to superior customer value and corporate performance". Second, in addition to not knowing what to change, managers perceive a dearth of guidelines about the implementation of market orientation in their organisation. They do not know how to make their product development efforts more market oriented, because academic research fails to provide specific implementable guidelines (Day, 1994b; Kahn \& Mentzer, 1994; Narver, Slater \& Tietje, 1998; Ruekert, 1992). A distinct and workable conceptualisation of market oriented product development is the first step towards understanding the implementation process.

This paper develops a conceptualisation of market-oriented product development, based on literature about market orientation, product development, the resource-based view of the firm, and organisational learning. It consists of 
two parts. In the first part of the paper we discuss the theoretical building blocks of our conceptualisation. We start by describing and evaluating the various perspectives on market orientation. Next, we discuss existing research that links market orientation with product development. Then we explain why we use the organisational learning perspective as a theoretical starting point for integrating market orientation with product development. In the second part of the paper we present, based on the building blocks from the first part, a framework representing our conceptualisation of market-oriented product development. In the subsequent sections, we discuss the major elements of our framework, illustrate them with case examples and explore the relationships between the elements. We conclude our paper by discussing the major conclusions and implications of our framework. Please note that our paper is conceptual by nature; the case examples are inserted for illustrative purposes only.

\section{Market Orientation}

Market orientation has its philosophical foundations in the marketing concept (Kohli \& Jaworski, 1990; Narver \& Slater, 1990). It has been constructed from three basic perspectives: market orientation as organisational behaviour, market orientation as organisational cognition, and market orientation as the combination or integration of behaviour and cognition.

According to behaviourists, market orientation reflects marketing behaviour or activities, consisting of the generation and dissemination of market intelligence, as well as the responsiveness to this market intelligence (e.g. Gatignon \& Xuereb, 1997; Jaworski \& Kohli, 1993; Kohli \& Jaworski, 1990; Ruekert, 1992) or in more general terms "the set of cross functional processes and activities directed at creating and satisfying customers through continuous needs-assessment" (Deshpandé \& Farley, 1998, p. 226). According to the cognitive perspective, this kind of behaviour is a consequence of having a market orientation, with the concept of market orientation referring to a culture or set of shared beliefs that put the customer's interests first, as well as the required knowledge systems and structures to achieve this (see e.g. Deshpandé, Farley \& Webster, 1993; Deshpandé \& Webster Jr, 1989; Han et al., 1998; Harris \& Piercy, 1997; Hurley \& Hult, 1998; Narver et al., 1998; Narver \& Slater, 1990; Narver \& Slater, 1998; Slater \& Narver, 1995). Note that although Narver and Slater (1990), and other authors following them such as Morgan, Katsikeas \& Appiah Adu (1998), conceptualise market orientation as a culture they still operationalise it using behavioural issues.

Both the behaviourist and cognitive perspectives have been criticised. The criticism directed at the cognitive perspective mainly concerns the measurement of shared beliefs and values, which is subject to conceptual and methodological 
problems (e.g. Allard-Poesi, 1998) and does not result in knowledge about desired organisational behaviour. The behavioural approach has been criticised for lacking a theoretical foundation (e.g. Dreher, 1993). Also, it has been argued that a behavioural perspective on market orientation is too restricted as activities are relatively easy to copy and therefore fail to result in any enduring competitive advantage while having a market orientation clearly does (Homburg \& Pflesser, 2000).

Not surprisingly, a number of studies combine the cognitive and behavioural perspectives (Avlonitis \& Gounaris, 1997; Baker \& Sinkula, 1999a; Baker \& Sinkula, 1999b; Homburg \& Pflesser, 2000). For example, Avlonitis and Gounaris (1997) see market orientation as the combination of attitude and activities. Other authors integrate both perspectives and view market orientation as a critical resource in organisational learning (Day, 1994a; Day, 1994b; Day \& Nedungadi, 1994; Hunt \& Morgan, 1995; Moorman, 1995; Sinkula, 1994; Slater \& Narver, 1995; Tuominen \& Möller 1996).

We propose to study market orientation (and consequently market-oriented product development) from an integrated cognitive and behavioural perspective for two reasons. First, full understanding of market orientation requires knowledge of both actual behaviour of organisations, and the quality of this behaviour (Jaworski \& Kohli, 1993; Jaworski \& Kohli, 1996). To investigate the quality of organisational behaviour we need insight in underlying beliefs, knowledge, structures and systems (Tuominen \& Möller, 1996). Second, the integrated cognitive/behavioural perspective is necessary when the aim is to generate managerial guidelines for changing an organisation's degree of market orientation. On the one hand, taking only a behavioural perspective does not suffice, because changes in behaviour may occur without the corresponding development of a firm's cognitive systems, resulting in long-term problems because the new behaviour is not supported by a changed cognitive structure. On the other hand, taking only a cognitive perspective would not suffice either, because changes in cognition may occur without resulting changes in organisational behaviour. Organisational learning theory, which integrates the cognitive and behavioural perspectives, offers a holistic approach to market-orientated product development and theoretically supports the organisational change point of view. It also acknowledges the complex relationship between cognition and behaviour, since although cognition may influence behaviour and vice versa, "one is not necessarily an accurate reflection of the other" (Fiol \& Lyles, 1985, p. 806). Thus, we adopt the third perspective and view market orientation as an organisational learning capability consisting of cognitive associations (e.g. shared beliefs, values and norms, and knowledge systems) and behavioural outcomes reflecting these cognitions. 


\section{Market Orientation Integrated with Product Development}

The literature on product development mainly aims at determining the factors that affect the performance of 1) the new product, 2) the product development project or 3) product development process (see Brown \& Eisenhardt, 1995; Poolton $\&$ Barclay, 1998). Taking into account these factors improves managing product development in organisations, that is in essence, deciding about new product strategy and controlling the development process (see e.g. Urban \& Hauser, 1993; Cooper, 2001; Tidd, Bessant \& Pavitt, 1997; Hart, 1996). The studies on product development describe it in various ways: as a functional (strategic) activity (e.g. Atuahene-Gima, 1995; Brown \& Eisenhardt, 1995; Niosi, 1999; Rothwell, 1992), as a process subdivided in activities or stages (e.g. Cooper, 1983; Cooper \& Kleinschmidt, 1991; Hart \& Baker, 1994; Saren, 1984), and, since the 1990s, as a capability (e.g. Leonard-Barton, 1992; Leonard-Barton, 1995; Lawson \& Samson, 2001 Subramaniam \& Venkatraman, 2001). In accordance with our aim we confine ourselves to describing the approaches of product development in association with market orientation.

As mentioned in the introduction, several researchers have studied the relationship between market orientation and product development, but they mainly focused on how market orientation influences innovation. The conceptualisation of market oriented product development (i.e. the integration of market orientation in product development processes) has received scant attention. Yet, some studies provide interesting insights in this topic.

A number of researchers use resource-based theory to identify the distinctive capabilities that constitute market-oriented product development. This corresponds with the cognitive perspective on market orientation as discussed in the previous section. According to resource-based theory, a firm employs both assets and capabilities to realise its objectives. Assets are resource endowments a firm has accumulated, such as investments in the scale, scope, and efficiency of facilities. Capabilities refer to the accumulated knowledge, skills, systems, methods, values and norms (Leonard-Barton, 1992; Leonard-Barton, 1995) which enable a firm to co-ordinate activities and use its assets (Day, 1994b). Studies taking such an organisational cognition perspective on the integration of market orientation with product development investigated e.g. (1) theoretical concepts such as competence and capability in the context of product development (Harmsen, 1994; Lukas \& Ferrell, 2000), (2) market orientation as a feature of a product development team (Burchill \& Fine, 1997), and (3) market information tools and techniques for product development (Griffin \& Hauser, 1993; Hauser \& Clausing, 1988; Nijssen \& Frambach, 2000; Workman Jr, 1993; Workman Jr, 1998). 
Market-oriented product development has also been studied as a series of market-related information processing activities (Sandell, 1994; Adams, Day \& Dougherty, 1998) or market-related functional activities (Cooper, 1983; Cooper $\&$ Kleinschmidt, 1994) in the context of a product development process. This clearly follows a behavioural perspective, where information is collected inside and outside the organisation, disseminated through the organisation, and used to perform various product development activities.

As stated in the previous section, we conceptualise market-oriented product development from an integrated cognitive and behavioural perspective, which views market-oriented product development as the combination of an organisational capability and the accompanying information processing behaviour directed at learning about markets. This integration of cognitive and behavioural perspectives is best understood from an organisational learning point of view.

\section{Organisational Learning Perspective}

Organisational learning is defined here as the process of improving actions through better knowledge and understanding (Fiol \& Lyles, 1985). Organisations learn through individuals (Dodgson, 1993; Kim, 1993). Individuals are able to learn and organisations are composed of these individuals. On the one hand, organisational learning may be "independent of a specific individual, but not independent of all individuals" (Kim, 1993, p. 37). On the other hand, organisational learning appears to be more than the sum of each individual's learning (Fiol \& Lyles, 1985). This individual learning enables an organisation to develop world views, ideologies and certain behaviours through cognitive systems (shared mental models) and memories. Thus, when the people involved in the development of new products are defined as a group (e.g. product development team), group learning may occur in product development (cf. Kim 1993). In other words, organisations may have a product development process which can be described as a learning process.

The organisational learning process can be described as a number of sequential information processing activities, as depicted in figure 1 (Day, 1994a; Fiol \& Lyles, 1985; Huber, 1991; Sinkula, 1994). An organisation learns about the market through a series of sequential information processing activities in terms of acquisition, distribution, interpretation, utilisation, and evaluation of market information (i.e. the behavioural part of market orientation). This information is subsequently communicated, interpreted, and accumulated, resulting in knowledge. The interpretation of market information occurs through a process of sorting, classification, and simplification. This learning process generates a context for market information and converts it into market knowledge that is part of 


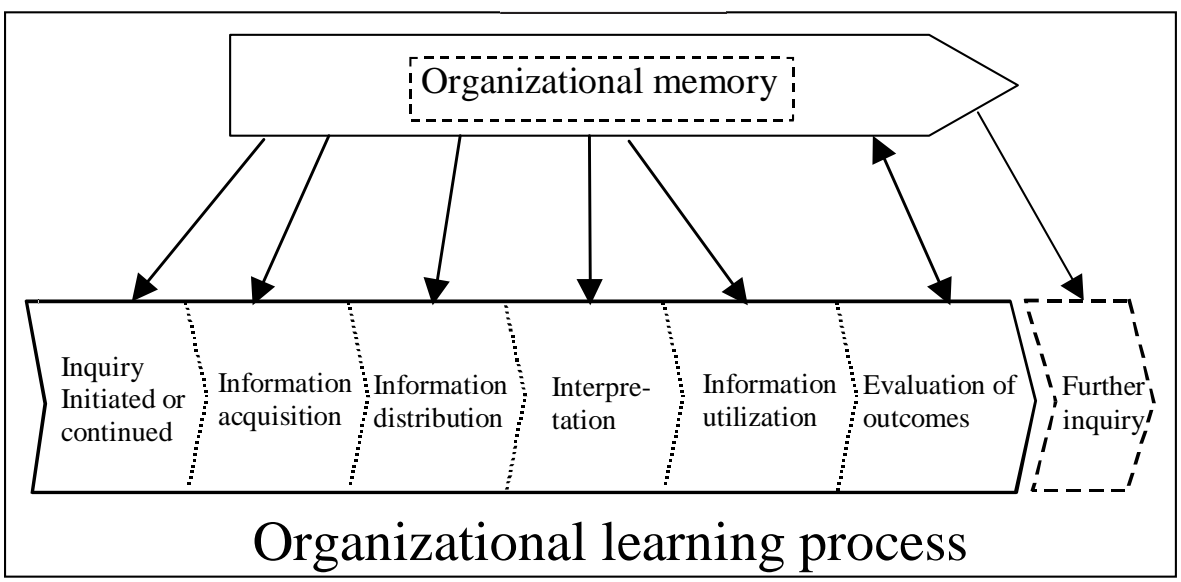

Fig. 1. An organizational learning process (based on Day 1994b).

organisational cognition. Thus, an organisation learns through acquiring information from the environment, conducting directed inquiries, imitating successful practices, or reflecting on past experiences (Day \& Nedungadi, 1994). This learning may occur at different levels (Fiol \& Lyles, 1985; Argyris \& Schön, 1996). Two levels of learning are relevant here. First, at the lower-level or single-loop learning, information is adjusted within the existing frame of reference. Second, information needs to be adjusted outside the existing frame of reference. This is the case of higher-level learning. Higher and lower-level learning can be can be applied to organisational learning about markets or market learning.

This market learning process may be influenced by barriers, such as the avoidance of ambiguity, compartmentalised thinking, and inertia (Adams et al., 1998). These barriers influence both what organisations do and what they say they do. In addition, an organisation's actions frequently differ substantially from its rhetoric (their walk is different from their talk) because of various other barriers (Pfeffer \& Sutton, 2000). In this paper, we do not focus on barriers influencing market learning and solving these barriers, but on gaining a better understanding and demonstrating how the organisation executes the market learning process, that is, on the quality of market information processing activities in the context of product development.

How these information processing activities are executed is determined by the firm's organisational cognitive elements. These include the individual and shared beliefs, knowledge and skills, which reside in the collective knowledge systems (such as databases, decision rules and standard operation procedures). These knowledge systems, together with existing shared mental models, function as the organisation's memory (Day \& Nedungadi, 1994; Deshpandé et al., 1993). 
This organisational learning perspective is applied to the context of product development. In creating a new product, a firm needs to make a number of decisions. Each decision triggers an information inquiry leading to information acquisition, distribution, interpretation and utilisation activities, according to the procedures and decision rules of existing knowledge systems and shared mental models. Through the activities depicted in Fig. 1, a firm gathers and combines market and technical information into knowledge about product specifications, product concepts, prototypes et cetera. Evaluation of these activities contributes to knowledge and skills to improve these activities and may also result in a search for missing knowledge to improve these activities. Thus, the explicit evaluation of product development activities and outcomes contributes to a firm's product development knowledge and skills.

While the firms' cognitive elements are represented by the firm's product development capability, in terms of knowledge, skills and systems, the behavioural elements consist of information processing activities during each stage of the product development process. Figure 2 shows product development as such a combined cognitive/behavioural construct. In the remainder of this paper, we

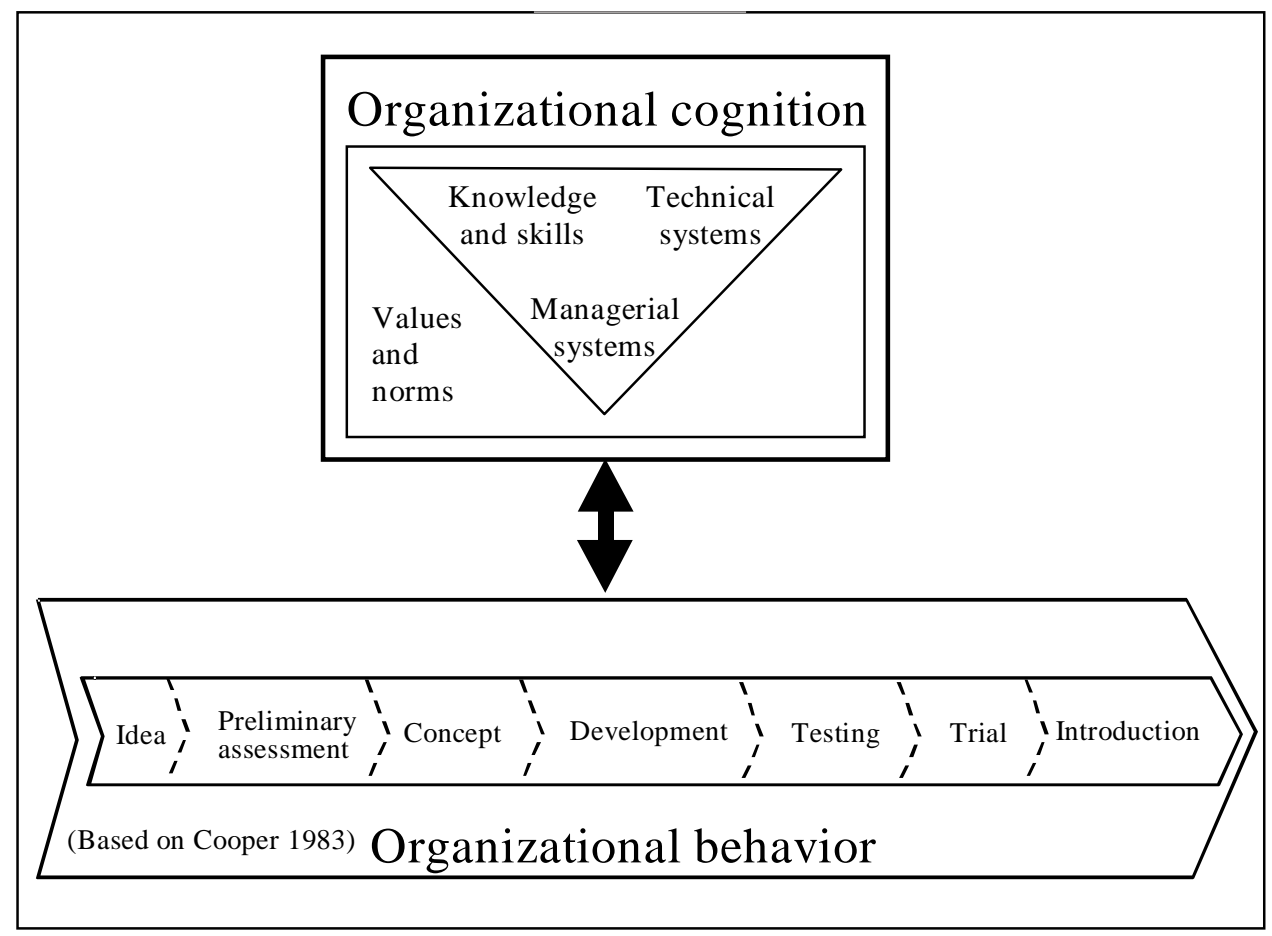

Fig. 2. Cognitive and behavioral perspective on product development. 
describe the organisational cognitive elements, how these elements influence product development activities (in terms of information processing activities) and how the firm's information processing activities in turn influence its cognitive elements. The description is illustrated with examples from two companies: Vroom and Press.

\section{Origin of the Illustrative Examples}

While this paper is conceptual by nature, describing and explaining our conceptualisation of market-oriented product development based on literature study, we illustrate it with examples to provide a better and more concrete insight in the presence and reciprocal influence of the cognitive and behavioural elements and their interrelationships. Our examples have been extracted from two case studies conducted in two business-to-business companies with moderate complex product development processes and a moderate to high degree of market-oriented behaviour: a truck manufacturer (Vroom) and a manufacturer of printing machines $(\text { Press })^{1}$. Both case studies were conducted through in-depth interviews and document analysis in line with Yin's explorative case research methodology (Yin, 1994). The in-depth interviews, 12 in total, were held with respondents including general managers, marketing managers, project leaders, and R\&D managers. General managers were interviewed to determine the degree of market information processing, identify relevant respondents and documents and get access to them. $R \& D$ and marketing managers were interviewed to approach the phenomenon in question from different and possibly opposing angles. Project leaders were included to get information about specific product development activities at various stages of the process. A letter explaining the research project, emphasising the confidentiality of the data and a shortlist of topics that would be discussed preceded the interviews. The interviews lasted an average of one and a half hours, were recorded, transcribed and processed into interview reports, which were checked by the respondents for accuracy and completeness. In addition to the in-depth interviews, we analysed available product development process documents, containing detailed descriptions of development tasks, activities, milestones and responsibilities assigned to people involved in the development process. These document analyses provided additional information, but also enabled us to check information from the interviews about the procedures incorporated in technical and managerial knowledge systems.

\footnotetext{
${ }^{1}$ The names of the companies are fictitious for confidentiality reasons.
} 


\section{A Conceptual Framework for Market Oriented Product Development}

As explained, the conceptual framework for market oriented product development consists of two building blocks: behaviour and cognition. We start by describing the rather straightforward behavioural part of the framework, i.e. the information processing activities in the context of product development at a market oriented (business-to-business) firm. Next, we describe the organisational cognitive elements, how these cognitive elements influence organisational behaviour, and how information processing activities in turn influence the cognitive elements.

\section{Organisational behaviour}

When developing new products, a business-to-business firm may collect information about both direct and indirect customers through group discussions, customer visits, direct observation, sales meetings, beta tests, customer satisfaction studies, published market research reports, line of business reports, archival information (e.g. post-mortems on previous product development projects) and the Internet. In addition to information about customers, firms also need to collect information about competitors, market trends, new technological developments, laws and governmental regulations. This type of information gathering is frequently summarised by the term "market sensing" (e.g. Day, 1994b). What type of information is collected and how it is collected depends on the stage of the development process. For example, in the idea generation stage market studies are relevant, whereas in the concept stage one needs specific input about customer requirements and the testing stage requires the participation of customers to evaluate the performance of developed prototypes under real-life circumstances.

Subsequently, the gathered market information needs to be disseminated across business functions. This may be accomplished through formal channels, such as written documents (memo's, newsletters, customer visit reports), e-mail networks, presentations and meetings, as well as through informal channels (Cross \& Prusak, 2002; Krackhardt \& Hanson, 1993). The critical issue concerns the determination of the kind of information that is needed by certain functions at a particular moment in time. Depending on the stage of the development process and the specific activities involved, different functions need to be involved.

During all product development stages, the collected and disseminated market information needs to be utilised in combination with the available technical information (Cooper, 1983). During the early stages, the product's technical and commercial feasibility need to be determined before substantial amounts of money get committed to the development project. But also during later stages, market 
information plays an important role in decision making about product concepts, prototypes and launch strategies.

The three activities of collecting, disseminating and using market information are performed during each stage of the product development process depicted in Fig. 2 and assist in the creation of market knowledge and conversion of this knowledge into a successful product.

The main focus of this paper is to gain a better understanding of the organisational cognitive elements in which these market learning activities are embedded and which enable these activities.

\section{Organisational cognition}

The market learning activities discussed above are enabled by the firm's market learning capability: the execution of these activities is embodied in cognitive elements such as market information processing knowledge and skills, technical systems and managerial systems, all of which are embedded in the firm's values and norms (Leonard-Barton, 1992; Leonard-Barton, 1995). Although we believe that a market learning capability consists of these four cognitive elements, the contents of these cognitive elements may differ across firms, depending on the size, the industry structure and dynamics, the extent of product newness and product development process characteristics (Atuahene-Gima, 1995; 1996). In this section, however, we do not focus on the differences across firms and industries, but we describe the essence of these cognitive elements and how the business-to-business firm's information processing activities are enabled by these elements. We also discuss how the firm's evaluation of these activities leads to enhanced knowledge and consequently improved technical and managerial systems and thus contributes to a firm's market learning.

\section{Values and norms}

Market-oriented values and norms refer to individual and shared beliefs which put the customer's interest first before historically rooted technical competence (Deshpandé et al., 1993; Lichtenthal \& Wilson, 1992). Sinkula (1994) refers to these fundamental values and norms as axiomatic knowledge when he describes them as the answer to the question "why are things done the way they are?" This knowledge is used to make sense of the product development context, e.g. the firm's target markets and the relevance and interpretation of market information. In a market-oriented organisation, the values and norms reflect the understanding that market information, especially customer and competitor information, is a critical input for the development process. This understanding of the importance 
of market information may be embodied in the firm's product development philosophy. For example, Press follows the philosophy that new printing machines should enable business customers to attain good results without any understanding of the underlying printing technique. This requires Press to translate its printing expertise into customer-friendly product characteristics. Likewise, Vroom values competitor information highly, which is demonstrated through its standard practice of reverse engineering competitor products to see how competitors made tradeoffs in matching technical characteristics to customer needs. These values and norms support the other three dimensions of organisational cognition by directing the content and interpretation of knowledge in these dimensions. In addition to information about customers and competitors, information about other relevant stakeholders, such as indirect customers, suppliers, manufacturers of complementary products, government agencies and research institutes needs to be taken into consideration.

The existence of market-oriented values and norms in product development needs to be distinguished from the firm's product development strategy, which can be described in terms of market pull versus technology push (Cooper, 1983, Kiel, 1984; Karlsson \& Ålström, 1997; Jaworski, Kohli \& Sahay, 2000). This product development strategy is considered as a managerial knowledge system and is described in more detail in the section of the same name.

\section{Knowledge and skills}

In the context of market-oriented product development, knowledge and skills (i.e. the ability to translate knowledge into action) refer to detailed individual and shared understanding of the kind of market information that is needed, why it is needed, when it is needed, and how it should be acquired, disseminated, and combined with technical information in order to create successful new products. Sinkula (1994) classifies this tacit knowledge into endorsed and procedural knowledge. Endorsed knowledge refers to an organisational system of policies and strategies, "the espoused way of doing things", which are the rules for acquiring, disseminating and interpreting information about markets. Procedural knowledge is represented in a task system governed by tacit rules, the routines that describe "how things are actually done". This individual and shared understanding is analogous to managerial representations, or mental models. It refers to the firm's ability to process information and determines the quality of the required information (Day \& Nedungadi, 1994).

This individual and shared understanding concerns knowing exactly what kind of market information is needed at every stage of the development process. For example, a firm needs to know whether it needs market information at the 
level of the individual customer, the market segment or the total market (Wayland $\&$ Cole, 1997). At the level of the individual customer the firm may ask which customers might be interested in joint development projects. At the market segment level it may identify the segments that appear to be most promising for rapid diffusion of the new product. And at the market level, the firm estimates market potential and growth. In addition to knowing what kind of market information is needed, one also needs to know when it is needed. For example, Vroom realised that it typically used market needs and wants too late in the development process and has stimulated the use of market information at an earlier stage. Obviously, market information is not restricted to customer needs, but also includes information about external factors that influence customer needs and wants (Kohli \& Jaworski, 1990).

In addition to knowledge about the kind of market information, a marketoriented firm also needs skills to collect this information (e.g. the ability to perform effective beta tests). On business-to-business markets, direct contact with customers is an important source of information, for example to define customer requirements or to evaluate prototypes (Cooper, 1983; Gouillart \& Sturdivant, 1994). A failure to understand how such information can be collected may be very problematic. For instance, although Press realised the importance of obtaining customer feedback on prototypes, it did not know exactly what kind of feedback customers should give. As a consequence, feedback from customers did not offer much insight and Press discovered much later that customers had serious problems with certain elements of the new printing machine. In addition, Press had only tested the product with a specific type of customer, as a result of which the product failed to meet general market requirements.

Next, a market-oriented firm needs to be effective at disseminating market information across business functions (Jaworski \& Kohli, 1993). At Press many members of product development teams did not think it necessary to distribute all information regarding the ongoing project. Similarly, not everyone took notice of all information supplied by other departments, because they were already overwhelmed with information or just did not understand how the information affected their own functioning. Thus, market-oriented firms understand precisely which information needs to be distributed to whom and in what format. Especially determining the right format may prove to be difficult because cultural differences between business functions frequently prevent the existence of shared mental models concerning product development. For example, it has been found time and again that differences between Marketing and $R \& D$ hinder the effective information exchange and co-ordination (e.g. Griffin \& Hauser, 1996; Gupta, Ray \& Wilemon, 1986; Moenaert \& Souder, 1990a; Moenaert \& Souder, 1990b; Song \& Parry, 1992). 
Finally, a market-oriented firm needs to understand and have the skills to use the acquired market information in decision making processes. For instance, decision makers need to be able to translate market information into technical requirements. Both Vroom and Press were rather experienced with this and had formalised this knowledge and these skills into extensive technical knowledge systems. For instance, Press formulates product specifications on the basis of cross-functional meetings with customers. Using Quality Function Deployment this market information is converted into the technical specifications of the product.

\section{Technical knowledge systems}

Technical knowledge systems constitute the formalisations of the before-mentioned endorsed knowledge and skills that enable market information processing behaviour. These systems are the result of long structuring and codification processes, which visualise and de-individualise knowledge and skills, and thus transform individual knowledge and skills into explicit organisational memory. Technical knowledge systems may take the form of procedures, manuals, tools, and even software and support the market information processing activities. For example, an organisation may have detailed procedures for its customer visit program, including rules about which information is required, how it can be obtained, who should be involved, and who plays what role (McQuarrie, 1991). Similarly, information dissemination activities may be embedded in procedures, which determine the format and the receivers of the information (Maltz \& Kohli, 1996). Vroom and Press both use Quality Function Deployment (QFD) to translate customer needs into product specifications systematically. Vroom even has rules to decide when to use certain procedures: QFD is only used to develop complex products that are new to the market and to the company. Similarly, Press formulated procedures for the participation of suppliers in the development team, regular meetings with research institutes, and keeping track of government regulations.

\section{Managerial knowledge systems}

Managerial knowledge systems represent formal and informal ways of controlling and creating knowledge and skills that enable market learning. Managerial knowledge systems take several forms, but can be classified into two types: systems aimed at creating market information processing knowledge and skills (knowledge-creating systems) and systems aimed at controlling the use of market information processing knowledge and skills (knowledge-controlling systems). Knowledge-creating systems enable the processing of information resulting in new (market information processing) knowledge and skills that may lead to the 
modification of technical and/or managerial knowledge systems. Knowledgecontrolling systems facilitate the systematic use of knowledge and skills, and the operation of technical systems.

Management may stimulate the creation of market information by various means. For instance, Press uses Total Quality Management (TQM) to improve its market information processing activities. TQM consists of procedures that describe the evaluation content, the evaluation process, and the formulation of improvement projects (e.g. adjusting the procedures for conducting beta tests). Other examples of managerial knowledge-creating systems are rewarding employees on the basis of customer satisfaction, training programs, internships, and co-operation with external partners.

Likewise, management has various instruments at its disposal to facilitate the use of knowledge and skills, as well as the operation of technical systems to process market information. One of them is the organisational product development structure that influences market information processing. This is analogous to the notion from organisational learning theory that variables such as openness (participative and reflective), centralisation and formalisation influence market information processing (Hult \& Ferrell, 1997; Jaworski \& Kohli, 1993). For example, Vroom created a separate department, called Product Planning, outside the traditional hierarchical R\&D and Marketing \& Sales departments. Product Planning gathers market information, uses it to develop broad insight into customer needs and wants and competitor product characteristics, and shares these insights with technical engineers. Consequently, market information was less distorted. A firm's organisational structure connects the various business functions involved in product development (for example through a project matrix structure), allows the creation of cross-functional product development teams and facilitates interfunctional co-ordination during information processing activities (Rochford \& Rudelius, 1992).

Another instrument for controlling the use of market information is a product development model that structures product development process activities (such as the famous stage-gate model; Cooper, 1994). Both Vroom and Press use a model consisting of several (parallel) development tasks, evaluation and decision moments and responsibilities. This model incorporates technical knowledge systems (procedures and tools such as QFD). Such a systematic and structured approach to product development helps both firms to effectively and efficiently collect, disseminate and use market information and thus enables them to control development costs, product quality and time-to-market. For instance, in the case of Press, the insufficient exchange of information between technicians and customers led the firm to train technicians in conducting customer visits and to add account managers to these customer visits. Thus, it stimulates direct contact 
between its own technicians and their customer counterparts, but uses account managers to co-ordinate the flows of communication. It facilitates this co-ordination by following a procedure for customer visits (technical knowledge system) and using an organisational matrix structure (managerial knowledge system) to control information processing. A product development process model may also include procedures for the dissemination and use of market information. Such procedures may turn out to be critical, since the possession of market information does not guarantee that the information is disseminated to the right persons and/or actually used (see also Rochford \& Rudelius, 1992). In the case of Press, such procedures were not present, resulting in insufficient cross-functional dissemination of market information.

Other knowledge-controlling systems are the firm's product development strategy and technology roadmaps. The product development strategy can be market-pull, technology-push or somewhere in between (Cooper, 1983; Kiel, 1984; Karlsson \& Ålström, 1997; Jaworski et al., 2000). This product development strategy as a managerial knowledge-controlling system needs to be distinguished from values and norms or product development philosophy. Choosing a marketpull strategy, the firm identifies customer needs and wants prior to product development based on customers demanding a product. But having market-oriented values and norms does not necessarily imply that one should start with explicit market demand. Indeed, a firm with market-oriented values and norms may also employ a technology-push strategy or a balanced combination of both market pull and technology push (Jaworski et al., 2000). However, in the case of a technology-push strategy, being market oriented requires that the firm investigates at an early stage of the development process whether there is sufficient market demand for the new technological functions to be developed. The product development strategy directs market information collection at the start (identifying and responding to customer demand in the case of market-pull) or in an early stage (finding lead-users in the case of technology-push) of product development. Technology roadmaps chart the technologies and the product/market combinations based on these technologies (Capon \& Glazer, 1987; Groenveld, 1997; Kappel, 2001; Kostoff \& Schaller 2001; Willyard \& McClees, 1987). A technology roadmap affects the product development strategy with the corresponding influence on market information collection (Groenveld, 1997). In addition, due to the dual nature of roadmaps, used for both developing a market vision and plans articulating a course of action (Kappel, 2001), they require collecting both corresponding types of market information. And systematically using technology roadmaps enables and improves interfunctional dissemination of technical and market information, e.g. communication about current and future technological and market positions (Groenveld, 1997). Enabling and improving interfunctional information 
dissemination is facilitated through a shared cognitive map manifested in a visual display aid providing the linkages between the technology and product development programmes, targets and requirements (Kostoff \& Schaller, 2001), and through accomplished alignment of priorities between marketing and technology groups in organisations (Kappel, 2001).

Specific management tools may contain elements of both knowledge-creating systems and knowledge-controlling systems. For example, although we presented product development process models as a knowledge-controlling system, they may also serve as a knowledge-creating system. The evaluation moments at the end of every stage, as well as the post-mortem after the development project is concluded, allow for reflection on the available market knowledge, the quality of the technical knowledge systems and the quality of the process model. A systematic evaluation of a firm's product development efforts is essential to get feedback on information processing activities (Crawford, 1986). When the process model and the embedded technical systems are adjusted because of this feedback and the improved model is applied to future product development projects, the firm increases its knowledge about how, when and why information processing activities need to be carried out.

Thus, the actual information processing activities may be carried out using procedures (technical knowledge systems) embedded in knowledge-controlling systems, translating knowledge from customers and other relevant parties into a product. Evaluation moments (go/no go decisions) residing in knowledge-creating systems can be used to determine whether the available market knowledge meets the required quality standards and whether additional information needs to be gathered. These evaluation moments can also be used to determine whether existing procedures for information collection, dissemination or utilisation (technical knowledge systems) need to be adjusted or whether managerial knowledge systems need to be altered to better embed these technical knowledge systems.

\section{Capabilities and activities at two levels}

The two components of market-oriented product development, i.e. a firm's capability and information processing activities, can be applied at the level of individual product development stages (as described above), but also at the level of the holistic product development process. At the level of individual stages, information processing activities are found at every stage of the process. At the level of the holistic development process, market-oriented product development can be thought of as organisational learning about markets and about the development of new products. This learning process consists of information 
acquisition, distribution, interpretation, and utilisation of information about previous development projects (experience and know-how), market trends and technology developments. For instance, evaluation of the product development process may bring to light that a changed competitive situation requires a faster time-to-market. This may result in the establishment of concurrent engineering, collaborative efforts with various partners and investments in information systems.

\section{Conclusions}

In this article we presented a framework that conceptualises market-oriented product development. In our opinion, it is more than just carrying out a product development process and performing a number of marketing activities. Marketoriented product development is a combination of (1) cognitive elements (values and norms, knowledge and skills, technical knowledge systems, and managerial knowledge systems) stimulating and facilitating and (2) market information processing activities, at both the level of the individual product development stages (idea generation, preliminary assessment, concept development etc.) and the level of the product development process as a whole.

The distinction between cognitive and behavioural elements is critical to fully understand market-oriented product development. It implies an emphasis on the quality of activities, rather than on the extent to which activities are performed. For example, before market information is collected, it is important to have an accurate understanding of the kind of market information required. In addition, from an organisational change perspective, managers need to combine these two perspectives if they want to formulate actionable guidelines for creating marketoriented product development. Cognitive development influences, but is not necessarily an accurate reflection of, behavioural development and vice versa (Fiol \& Lyles, 1985).

Our conceptualisation also reveals that, in essence, market-oriented product development is an organisational learning capability at two levels. Market-oriented product development is all about learning about market trends and technological developments which affect the whole process, and about learning from customers, competitors, other stakeholders, and product development activities, which affect individual product development stages.

Market-oriented product development is definitely complex and therefore difficult to implement. Whereas simply regarding it as a set of activities or a culture would offer only a limited perspective and may thwart implementation efforts, our conceptual framework, regarding it as an organisational learning capability, captures this complexity and presents a more realistic and useful picture. On the positive side, the fact that market-oriented product development 
is complex and difficult to implement also implies that it is difficult to copy and thus may serve as a sustainable competitive advantage. For market-oriented product development to function as a truly superior capability, a firm needs an organisational learning process that is more systematic, thoughtful and anticipatory than is found in other firms (Day, 1994b). That is, the continuous execution, evaluation and improvement of market information processing activities should be second nature to all parties involved, requiring individual and shared mental maps that focus on present and future market requirements, competitor actions, and inter-functional co-ordination.

\section{Implications for Research and Management Practice}

This paper presents the first tentative holistic conceptual framework for marketoriented product development, integrating cognitive and behavioural approaches to market orientation and applying them to the context of product development. By explaining the essence and complexity of market-oriented product development we provided a sound basis for further research on this topic. Since this is a tentative conceptual framework and only illustrated with examples from two cases, an empirical follow-up is needed to further operationalise, test and further detail the framework. For instance, future researchers may further investigate the interaction between organisational behaviour and cognition, the functioning of organisational memory, the interaction between individual and organisational learning in product development and the various effects of different management practices. In doing so, researchers should take into account that the framework's cognitive and behavioural elements, as well as the relationship between them, may differ across firms of different sizes and belonging to different industries, and vary according to the extent of product newness and product development process characteristics (Atuahene-Gima, 1995; Atuahene-Gima, 1996).

Future research also needs to be directed at how market-oriented product development can be implemented and/or improved within the organisation. More specifically, answers should be found to the following questions. What problems might occur when a firm tries to increase its level of market-oriented product development? How can managers solve these problems? What are the antecedents, obstacles and facilitators for implementing market-oriented product development? Gaining insight into these critical issues necessitates the operationalisation of the cognitive part of market-oriented product development (Biemans, 1995; Biemans \& Harmsen, 1995).

Managers may use the resulting detailed framework and guidelines for implementation to make their product development processes more marketoriented. Even in the tentative form in which it is presented here, it: 
- offers them a holistic view on various cognitive and behavioural elements that must be taken into account and how they are related;

- shows that not the activities per se but rather the way the activities are performed is paramount and how the cognitive elements of the model may be used to improve the quality of these activities; and

- demonstrates that market information processing activities need to be embedded in the very fabric of the organisation.

As such, they may use the framework to enhance organisational learning about markets and thus create a competitive advantage.

Firms need to cope with increasing global competition, forcing them to closely monitor competitors, decrease the costs of organisational processes and continuously map market requirements. However, firms still spend huge amounts of time and money on unsuccessful product development projects (Page, 1993). Making these product development processes more market-oriented helps firms to increase the chances of success. Moreover, several authors have argued that firms should start implementing market orientation in a core organisational process and product development seems to be an ideal candidate (Barabba, 1995; Day, 1994b; Deschamps \& Nayak, 1995). Thus, transforming the product development process into a more market-oriented one can be considered as the first step in implementing a market orientation in the rest of the organisation, thus further increasing the firm's competitive advantage.

\section{Acknowledgements}

We thank Isabelle S.J. Maignan for her thoughtful suggestions. We are also grateful to one anonymous reviewer of the Research School "Systems, Organisation and Management" (University of Groningen), two anonymous reviewers of the Academy of Marketing Science 2000 Conference and two anonymous reviewers of this journal for their insightful comments on an earlier version of this paper.

\section{References}

Adams, M.E., Day, G.S. \& Dougherty, D. (1998) Enhancing new product development performance: An organizational learning perspective. Journal of Product Innovation Management, 15, 403-422

Allard-Poesi, F. (1998) Representations and influence processes in groups: Towards a socio-cognitive perspective on cognition in organization. Scandinavian Journal of Management, 14(4), 395-420

Argyris, Chris \& Schön, Donald A. (1996) Organizational Learning II. Theory, Method, and Practice. Reading, MA: Addison-Wesley 
Atuahene-Gima, K. (1995) An exploratory analysis of the impact of market orientation on new product performance. Journal of Product Innovation Management, 12, 275-293 (1996) Market orientation and innovation. Journal of Business Research, 35, 93-103

Avlonitis, G.J. \& Gounaris, S.P. (1997) Marketing orientation and company performance. Industrial Marketing Management, 26, 385-402

Baker, W.E. \& Sinkula, J.M. (1999a) Learning orientation, market orientation, and innovation: Integrating and extending models of organizational performance. Journal of Market-Focused Management, 4, 295-308

(1999b) The synergistic effect of market orientation and learning orientation on organizational performance. Journal of the Academy of Marketing Science, 27(4), 411-427

Barabba, V. P. (1995) Meeting of the Minds; Creating the Market-Based Enterprise. Boston, MA: Harvard Business School Press

Barclay, I. (1992) The new product development process: Part 1 - Past evidence and future practical application. $R \& D$ Management, 22(3), 255-263

Biemans, W.G. (1995) Implementing market-oriented product development. Technology Review, 83 (September), 47-53

Biemans, W.G. \& Harmsen, H. (1995) Overcoming the barriers to market-oriented product development. Journal of Marketing Practice, 1(2), 7-25

Brown, S.L. \& Eisenhardt, K.M. (1995) Product development: Past research, present findings, and future directions. Academy of Management Review, 20(2), 343-378

Burchill, G. \& Fine, C.H. (1997) Time versus market orientation in product concept development: Empirically-based theory generation. Management Science, 43(4), $465-478$

Capon, N. \& Glazer, R. (1987) Marketing and technology: A strategic coalignment. Journal of Marketing, 51(July), 1-14

Cooper, R.G. (1983) A process model for industrial new product development. IEEE Transactions on Engineering Management, 30(1), 2-11

(1994) Third-generation new product processes. Journal of Product Innovation Management, 11, 3-14

(2001) Winning at New Products: Accelerating the Process from Idea to Launch, 3rd edn. Cambridge, MA: Perseus

Cooper, R.G. \& Kleinschmidt, E.J. (1991) New product processes at leading industrial firms. Industrial Marketing Management, 20, 137-147

(1993) New-product success in the chemical industry. Industrial Marketing Management, 22, 85-99

(1994) Determinants of timeliness in product development. Journal of Product Innovation Management, 11, 381-396

(1995) Performance typologies of new product projects. Industrial Marketing Management, 24, 439-456

Crawford, C.M. (1986) Evaluating new products: A system, not an act. Business Horizons, 29(November-December), 48-55 
Cross, R. \& Prusak, L. (2002) The people who make organizations go - or stop. Harvard Business Review, 80(June), 104-112

Day, G.S. (1994a) Continuous learning about markets. California Management Review, (Summer), 9-31

(1994b) The capabilities of market-driven organizations. Journal of Marketing, 58(October), 37-52

Day, G.S. \& Nedungadi, P. (1994) Managerial representations of competitive positioning. Journal of Marketing, 58(2), 31-44

Deschamps, J.P. \& Nayak, P.R. (1995) Product Juggernauts - How Companies Mobilize to Generate a Stream of Market Winners. Boston, MA: Harvard Business School Press

Deshpandé, R. \& Farley, J.U. (1998) Measuring market orientation: Generalization and synthesis. Journal of Market-Focused Management, 2, 213-232

Deshpandé, R., Farley, J.U. \& Webster, J. (1993) Corporate culture, customer orientation, and innovativeness in Japanese firms. Journal of Marketing, 57(January), 23-37

Deshpandé, R. \& Webster Jr, F.E. (1989) Organizational culture and marketing: Defining the research agenda. Journal of Marketing, 53(January), 3-15

Dodgson, M. (1993) Organizational learning: A review of some literatures. Organization Studies, 14(3), 375-394

Dreher, A. (1993) Marketing orientation: How to grasp the phenomenon? Emac Proceedings. Barcelona, 375-393

Fiol, C.M. \& Lyles, M.A. (1985) Organizational learning. Academy of Management Review, 10(4), 803-813

Gatignon, H. \& Xuereb, J.M. (1997) Strategic orientation of the firm and new product performance. Journal of Marketing Research, 34(February), 77-90

Gouillart, F.J. \& Sturdivant, F.D. (1994) Spend a day in the life of your customers. Harvard Business Review, (January-February), 117-125

Greenley, G.E. (1995) Forms of market orientation in UK companies. Journal of Management Studies, 32(1), 47-66

Griffin, A. \& Hauser, J.R. (1993) The voice of the customer. Marketing Science, 12(1), $223-253$

(1996) Integrating R\&D and Marketing: A review and analysis of the literature. Journal of Product Innovation Management, 13, 191-215

Groenveld, P. (1997) Roadmapping integrates business and technology. Research and Technology Management, (September-October), 48-55

Gupta, A.K., Ray, S.P. \& Wilemon, D. (1986) A model for studying R\&D-Marketing interface in the product innovation process. Journal of Marketing, 50(April), 7-17

Han, J.K., Kim, N. \& Srivastava, R.K. (1998) Market orientation and organizational performance: Is innovation a missing link? Journal of Marketing, 62, 30-45

Harmsen, H. (1994) Product development practice in medium-sized food processing companies: Increasing the level of market orientation. IPDMA Conference Proceedings. Gothenburg, 286-300 
Harris, L.C. \& Piercy, N.F. (1997) Market orientation is free: The real costs of becoming market-led. Management Decision, 35(1), 33-38

Hart, S. (1996) New Product Development: A Reader. London: The Dryden Press

Hart, S.J. \& Baker, M.J. (1994) Multiple convergent processing model of new product development. International Marketing Review, 11(1), 77-92

Hauser, J.R.\& Clausing, D. (1988) The house of quality. Harvard Business Review (MayJune), 63-73

Homburg, Ch. \& Pflesser, Ch. (2000) A multiple-layer model of market-oriented organizational culture: Measurement issues and performance outcomes. Journal of Marketing Research, 37(November), 449-462

Huber, G.P. (1991) Organizational learning: The contributing processes and the literatures. Organizational Science, 2(1), 88-115

Hult, G.Th.M. \& Ferrell, O.C. (1997) A global learning organization structure and market information processing. Journal of Business Research, 40, 155-166

Hunt, S.D. \& Morgan, R.E. (1995) The comparative advantage theory of competition. Journal of Marketing, 59(April), 1-15

Hurley, R.F. \& Hult, G.Th.M. (1998) Innovation, market orientation, and organizational learning: An integration and empirical examination. Journal of Marketing, 62, $42-54$

Jaworski, B.J. \& Kohli, A.K. (1993) Market orientation: Antecedents and consequences. Journal of Marketing, 57(July), 53-70

(1996) Market orientation: Review, refinement, and roadmap. Journal of Market-Focused Management, 1, 119-135

Jaworski, B.J., Kohli, A.K. \& Sahay, A. (2000) Market-driven versus driving markets. Journal of the Academy of Marketing Science, 28(1), 45-54

Kahn, K.B. \& Mentzer, J.T. (1994) Norms that distinguish between Marketing and Manufacturing. Journal of Business Research, 30, 111-118

Kappel, Th.A. (2001) Perspectives on Roadmaps: How organizations talk about the future. Journal of Product Innovation Management, 18, 39-50.

Karlsson, C. \& Ålström, P. (1997) Perspective: Changing product development strategy - A managerial challenge. Journal of Product Innovation Management, 14, $373-484$

Kiel, G. (1984) Technology and Marketing: the magic mix? Business Horizons, (MayJune), 7-14

Kim, D.H. (1993) The link between individual and organizational learning. Sloan Management Review, (Fall), 37-50

Kohli, A.K. \& Jaworski, B.J. (1990) Market orientation: The construct, research propositions, and managerial implications. Journal of Marketing, 54(April), 1-18

Kohli, A.K., Jaworski, B.J. \& Kumar, A. (1993) MARKOR: A measure of market orientation. Journal of Marketing Research, 30(November), 467-477

Kostoff, R.N. \& Schaller, R.R. (2001) Science and technology roadmaps. IEEE Transactions on Engineering Management, 48(2), 132-143 
Krackhardt, D. \& Hanson, J.R. (1993) Informal networks: The company behind the chart. Harvard Business Review, 71 (July-August), 104-110

Lawson, B. \& Samson, D. (2001) Developing innovation capability in organisations: A dynamic capabilities approach. International Journal of Innovation Management, 5(3), 377-400

Leonard-Barton, D. (1992) Core capabilities and core rigidities: A paradox in managing new product development. Strategic Management Journal, 13, 111-125

(1995) Wellsprings of Knowledge: Building and Sustaining the Sources of Innovation. Boston, MA: Harvard Business School Press

Li, T. \& Calantone, R.J. (1998) The impact of market knowledge competence on new product advantage: Conceptualization and empirical examination. Journal of Marketing, 62(October), 13-29

Lichtenthal, J.D. \& Wilson, D.T. (1992) Becoming market oriented. Journal of Business Research, 24, 191-207

Lukas, B.A. \& Ferrell, O.C. (2000) The effect of market orientation on product innovation. Journal of the Academy of Marketing Science, 28(2), 239-247

Maltz, E. \& Kohli, A.K. (1996) Market intelligence dissemination across functional boundaries. Journal of Marketing Research, 33(February), 47-61

McQuarrie, E.F. (1991) The customer visit: Qualitative research for business-to-business marketers, Marketing Research, (March), 15-28

Moenaert, R.K. \& Souder, W.E. (1990a) An analysis of the use of extrafunctional information by R\&D and Marketing personnel: Review and model. Journal of Product Innovation Management, 7, 213-229

(1990b) An information transfer model for integrating Marketing and R\&D personnel in new product development projects. Journal of Product Innovation Management, 7, 91-107

Montoya-Weiss, M.M. \& Calantone, R.J. (1994) Determinants of new product performance: A review and meta-analysis. Journal of Product Innovation Management, 11, $397-417$

Moorman, C. (1995) Organizational market information processes: Cultural antecedents and new product outcomes. Journal of Marketing Research, 32(August), 318-335

Morgan, R.E., Katsikeas, C.S. \& Appiah-Adu, K. (1998) Market orientation and organizational learning capabilities. Journal of Marketing Management, 14, 353-381

Narver, J.C. \& Slater, S.F. (1990) The effect of a market orientation on business profitability. Journal of Marketing, 54(October), 20-35

(1998) Additional thoughts on the measurement of market orientation: A comment on Deshpandé and Farley. Journal of Market-Focused Management, 2, 233-236

Narver, J.C., Slater, S.F. \& Tietje, B. (1998) Creating a market orientation. Journal of Market-Focused Management, 2, 241-255

Nijssen, E.J. \& Frambach, R.T. (2000) Determinants of the adoption of new product development tools by industrial firms. Industrial Marketing Management, 29, 121-131 
Niosi, J. (1999) Fourth-Generation R\&D: From linear models to flexible innovation. Journal of Business Research, 45, 111-117

Page, A.L. (1993) Assessing new product development practices and performance: Establishing crucial norms. Journal of Product Innovation Management, 10, 273-290

Pelham, A.M. \& Wilson, D.T. (1996) A longitudinal study of the impact of market structure, firm structure, strategy, and market orientation culture on dimensions of small-firm performance. Journal of the Academy of Marketing Science, 24(1), 27-43

Pfeffer, J. \& Sutton, R.I. (2000) The Knowing-Doing Gap: How Smart Companies Turn Knowledge Into Action. Boston, MA: Harvard Business School Press

Poolton, J. \& Barclay, I. (1998) New product development from past research to future applications. Industrial Marketing Management, 27, 197-212

Rochford, L. \& Rudelius, W. (1992) How involving more functional areas within a firm affects the new product process. Journal of Product Innovation Management, 9, 287-299

Rothwell, R. (1992) Successful industrial innovation: Critical factors for the 1990s. $R \& D$ Management, 22(3), 221-239

Ruekert, R.W. (1992) Developing a market orientation: An organizational strategy perspective. International Journal of Research in Marketing, 9, 225-245

Sandell, J. (1994) Management of market information in early stage product development. Proceedings EIASM. 579-592

Saren, M.A. (1984) A classification and review of models of the intra-firm innovation process. $R \& D$ Management, 14(1), 11-24

Sinkula, J.M. (1994) Market information processing and organizational learning. Journal of Marketing, 58(January), 35-45

Slater, S.F. \& Narver, J.C. (1994) Market orientation, customer value, and superior performance. Business Horizons, (March-April), 22-28

(1995) Market orientation and the learning organization. Journal of Marketing, 59(July), 63-74

(1996) Competitive strategy in market-focused business. Journal of MarketFocused Management, 1, 159-174

(2000) The positive effect of a market orientation on business profitability: A balanced replication. Journal of Business Research, 48, 69-73

Song, X.M. \& Parry, M.E. (1992) The R\&D-Marketing interface in Japanese high-technology firms. Journal of Product Innovation Management, 9, 91-112

Subramaniam, M. \& Venkatraman, N. (2001) Determinants of transnational new product development capability: Testing the influence of transferring and deploying tacit overseas knowledge. Strategic Management Journal, 22, 359-378

Tidd, J., Bessant, J. \& Pavitt, K. (1997) Managing Innovation. Integrating Technological, Market and Organizational Change. Chichester: John Wiley \& Sons

Tuominen, M. \& Möller, K. (1996) Market orientation: A state-of-the-art review. EMAC Proceedings. Budapest, 1161-1181 
Urban, G.L. \& Hauser, J.R. (1993) Design and Marketing of New Products, 2nd edn. Englewood Cliffs, NJ: Prentice Hall

Wayland, R.E. \& Cole, P.M. (1997) Customer Connections: New Strategies for Growth. Boston, MA: Harvard Business School Press

Willyard, C.H. \& McClees, C.W. (1987) Motorola's technology roadmap process. Research Management, (September-October), 13-19

Workman Jr, J.P. (1993) Marketing's limited role in new product development in one computer systems firm. Journal of Marketing Research, 30(November), 405-421

Workman Jr, J.P. (1998) Factors contributing to marketing's limited role in product development in many high-tech firms. Journal of Market-Focused Management, 2, 257-279

Wren, B.M., Souder, W.E. \& Berkowitz, D. (2000) Market orientation and new product development in global industrial firms. Industrial Marketing Management, 29, 601-611

Yin, R.K. (1994) Case Study Research: Design and Methods. London: Sage 